\title{
Screening of Urinary Crystals among Egyptian Children in South Sinai
}

\author{
Gamal Abd El Nasser Yamamah, Soha M. Abd El Dayem, Emad Salama, Hasan Salama, Mohamed Shoman
}

Pediatrics Department, National Research Centre, Cairo, Egypt

\begin{abstract}
Citation: Yamamah GAE, EI Dayem SMA, Salam E, Salama H, Shoman M. Screening of Urinary Crystals among Egyptian Children in South Sinai. Maced J Med Sci. 2013 Mar 15: 6(1):37-40 . http: /dx.doi.org/10.3889/MJMS.1957 5773.2012.0267.

Key words: urinary crystals; Egyptian children; South Sinai.

Correspondence: Soha M. Abd El dayem, Prof. of Pediatrics, Consultant of Endocrinology, National Research Centre, Cairo, Egypt. Tel: 0106716852 . E-mail: S_elday

Received: 16-Jan-2012; Revised: 13-Apr-2012; Accepted: 24-Apr-2012; Online first: 19-Nov-2012

Copyright: (c) 2012 Yamamah GAE. This is an open-access article distributed under the terms of the Creative Commons Attribution License, which permits unrestricted use, distribution, and reproduction in any medium, provided the original author and source are credited.

Competing Interests: The author have declared that no competing interests exist.
\end{abstract}

\section{Introduction}

Inappropriate dietary habits and changes in lifestyle are the factors that might contribute considerably to the increasing incidence and prevalence of urolithiasis; however, the exact underlying mechanisms are still unclear. It has been well documented that numerous dietary factors can alter urinary composition and super saturation, which can ultimately affect the process of stone formation [1]. Dietary oxalate, calcium, protein, purines, sodium, and ascorbic acid are known to be promoters of stone formation, and citrate and magnesium have been shown to be effective inhibitors [2].

There is marked variation in the pattern of urolithiasis in children in developed and developing countries [3]. Pediatric urolithiasis remains endemic in developing countries, affecting children of less than 1 year to adolescence. The prevalence rate is high at 5$15 \%$ in developing countries compared to $1-5 \%$ in developed countries [4].

The aim of our study is to evaluate the prevalence of urinary crystals among Egyptian children in different locality of South Sinai. Also to determine risk factors that are most significant in predicting crystal in urine to identify which children will need follow up to avoid the occurrence of stone. 


\section{Subject and Methods}

It is a cross sectional observational study, performed after obtaining approval by the ethical committee of the National Research Centre. Written informed consent was obtained from all patients and their parents after full discussion about the aim of the study. The study included 1918 healthy children from South Sinai, their mean age ranged from 6- 14 years (primary and preparatory schools). It included 994 males and 924 females. South Sinai has 8 cities and Children were selected randomly from six localities only on stratified basis. The selected cities are the same as the other two cities regarding population origin, Bedouine tribes, environmental conditions and dietary habits. The study include 661 child from El- Tur, 320 from Saint Katrin , 159 from Abo Redeis, 212 from Abo Zeneima, 356 from Ras Sidr and 210 from Nuweiba. Both Bedouine and urban inhabitants was found in the 6 localities. Urban origin predominates in El- Tur and Ras Sidre cities, while bedouines predominate in the other 4 cities.

History of any previous renal problems were taken from all patients. Renal problems include the following: 1- Acute renal manifestations (dysuria, polyuria, frequency, urgency, urine discoloration, incontinence). 2- Chronic or recurrent renal manifestations. 3- history of renal investigations ( $X$ Ray, Sonar, non routine urine analysis, history of renal surgery)

Fresh urine samples was centrifuged and examined microscopically to search for the presence of any type of crystal.

\section{Statistical methods}

Statistical Analyses were performed with Statistical Package for Social Science (SPSS) program for widows (Chicago, USA version 13.0). Chi- Square test was used for analysis of qualitative data.

The appropriate sample size for a populationbased survey is determined largely by three factors: (i) the estimated prevalence of the variable of interest chronic malnutrition in this instance, (ii) the desired level of confidence and (iii) the acceptable margin of error.

For a survey design based on a simple random sample, the sample size required can be calculated according to the following formula:

$$
n=t^{2 *} p(1-p)
$$$$
\mathrm{m}^{2}
$$

$\mathrm{n}=$ required sample size; $\mathrm{t}=$ confidence level at
95\% (standard value of 1.96); $p=$ estimated prevalence of malnutrition in the project area; $\mathrm{m}=$ margin of error at $5 \%$ (standard value of 0.05). Final Sample Size: N = 690 children. We have expanded the size of the sample to increase the confidence limit.

\section{Results}

None of the examined children has given a history of chronic or recurrent renal problem. None of them was complaining of acute renal problem at the time of urine collection. About $28.99 \%$ of the examined urine samples were positive for crystals. About $2.8 \%$ of the children (53 children) had more than one type of crystals, and $71.1 \%$ of the examined children had no crystals in their urine.

Table 1: Percentage of crystals in urine in different localities of South Sinai.

\begin{tabular}{|c|c|c|c|c|c|c|c|c|c|c|}
\hline \multicolumn{2}{|c|}{ Type of crystals } & $\begin{array}{c}\text { El- } \\
\text { Tur } \\
(661)\end{array}$ & $\begin{array}{c}\text { Abo } \\
\text { Redeis } \\
\text { (159) }\end{array}$ & $\begin{array}{c}\text { Abo } \\
\text { Zeneima } \\
(212)\end{array}$ & $\begin{array}{l}\text { Ras } \\
\text { Sidre } \\
(356)\end{array}$ & $\begin{array}{c}\text { Saint } \\
\text { Katrin } \\
(320)\end{array}$ & $\begin{array}{c}\text { Nuweiba } \\
(210)\end{array}$ & $\begin{array}{l}\text { All Cities } \\
\text { (1918) }\end{array}$ & $x^{2}$ & $\mathrm{p}$-value \\
\hline Oxalate & $\begin{array}{l}\text { No } \\
\%\end{array}$ & $\begin{array}{l}164 \\
24.8\end{array}$ & $\begin{array}{l}12 \\
7.5\end{array}$ & $\begin{array}{l}34 \\
16\end{array}$ & $\begin{array}{l}23 \\
6.5\end{array}$ & $\begin{array}{l}35 \\
10.9\end{array}$ & $\begin{array}{c}32 \\
15.2\end{array}$ & $\begin{array}{l}300 \\
15.64\end{array}$ & 78.17 & $<0.0001$ \\
\hline Uric acid & $\begin{array}{l}\text { No } \\
\%\end{array}$ & $\begin{array}{c}3 \\
05\end{array}$ & $\begin{array}{r}63 \\
396\end{array}$ & 29 & $\begin{array}{c}69 \\
194\end{array}$ & $\begin{array}{c}58 \\
18.1\end{array}$ & $\begin{array}{l}20 \\
95\end{array}$ & $\begin{array}{c}242 \\
1262\end{array}$ & 219.5 & $<0.0001$ \\
\hline $\begin{array}{c}\text { Triple } \\
\text { Phosphate }\end{array}$ & $\begin{array}{l}\text { No } \\
\%\end{array}$ & $\begin{array}{l}0 \\
0\end{array}$ & $\begin{array}{c}0 \\
0 \\
0\end{array}$ & $\begin{array}{c}4 \\
1.9\end{array}$ & $\begin{array}{l}0 \\
0 \\
0\end{array}$ & $\begin{array}{c}8 \\
2.5\end{array}$ & $\begin{array}{c}2 \\
2 \\
1.0\end{array}$ & $\begin{array}{l}14 \\
0.73\end{array}$ & 26.54 & $<0.0001$ \\
\hline
\end{tabular}

Chi- Square test was used.

Urine analysis revealed that the highest percent of urinary crystals were found among children from Abo redeis $(47.1 \%)$ and the least was in El- Tur $(25.3 \%)$ as shown in Table 1 . The most frequent crystals in the urine of the examined children was oxalate $(15.6 \%)$, then uric acid $(12.6 \%)$, and less than $1 \%$ of the samples was positive for triple phosphate crystals (Table 1). Oxalate was significantly higher in El- Tur, followed by Abo Zeneima then Nuweiba. Uric acid seemed to be significantly higher in Abo Redeis followed by Ras Sidre then Saint Katrin. Triple phosphate was significantly higher in Saint Katrin followed by Abo Zeneima, then Nuweiba (table 1). City was the most frequent risk factor for the 3 crystals (oxalate, uric acid and triple phosphate)

Table 2: Percentage of different types of urinary crystals according to gender, origin and consanguinity.

\begin{tabular}{|c|c|c|c|c|c|c|c|c|c|c|}
\hline \multirow{2}{*}{\multicolumn{2}{|c|}{$\begin{array}{c}\text { Type of crystals } \\
\text { (1918) }\end{array}$}} & \multicolumn{2}{|c|}{ Gender } & \multirow{2}{*}{$\begin{array}{c}\text { Chi - } \\
\text { square } \\
\left.\mid X^{2}\right) p \\
- \text { value } \\
3815\end{array}$} & \multicolumn{2}{|c|}{ Origin } & \multirow{3}{*}{$\begin{array}{l}\text { Chi- } \\
\text { square } \\
\left.\mid X^{2}\right) p- \\
\text { value } \\
0.000\end{array}$} & \multicolumn{2}{|c|}{ Consanguinity } & \multirow{2}{*}{$\begin{array}{c}\text { Chi- } \\
\text { square } \\
\left.\mid X^{2}\right) p- \\
\text { value }\end{array}$} \\
\hline & & $\begin{array}{l}\text { Males } \\
(994)\end{array}$ & $\begin{array}{c}\text { Females } \\
(924)\end{array}$ & & $\begin{array}{c}\text { Bedouine } \\
755\end{array}$ & $\begin{array}{c}\text { Urban } \\
506\end{array}$ & & $\begin{array}{l}\text { Negative } \\
(1146)\end{array}$ & $\begin{array}{l}\text { Positive } \\
\text { (508) }\end{array}$ & \\
\hline Oxalate & No & $\begin{array}{l}171 \\
172\end{array}$ & 129 & & 88 & $\begin{array}{c}59 \\
1117\end{array}$ & & 205 & 63 & \\
\hline & & $\begin{array}{l}17.2 \\
131\end{array}$ & $\begin{array}{l}14.0 \\
111\end{array}$ & $\begin{array}{l}(0.05) \\
0.591\end{array}$ & 11.7 & 11.7 & NS & 17.9 & 12.4 & 0.005 \\
\hline Uric acid & No & 131 & 111 & 0.591 & 162 & 65 & 15.003 & 91 & 83 & 26.37 \\
\hline & No & $\begin{array}{c}13.2 \\
8\end{array}$ & $\begin{array}{l}12.0 \\
6\end{array}$ & NS & $\begin{array}{c}21.5 \\
8\end{array}$ & $\begin{array}{l}12.8 \\
6\end{array}$ & $<0.0001$ & $\begin{array}{c}7.9 \\
8\end{array}$ & 16.3 & $<0.0001$ \\
\hline Phosphate & $\%$ & 0.8 & 0.6 & NS & 1.1 & 1.2 & NS & 0.7 & 1.0 & NS \\
\hline
\end{tabular}

Chi- Square test was used. 
(Table 1) followed by origin and consanguinity (Table 2 ). There were no significant differences between males and females according to the type of crystals in urine, except for oxalate in which males were significantly higher than females (Table 2). Uric acid crystals were significantly higher in children from bedouine area compared to urban area. On the other hand, there were no significant differences between the two areas in relation to other types of crystals (Table 2). Uric acid crystals were significantly higher in children with positive consanguinity (Table 2).

\section{Discussion}

About $28.99 \%$ of the examined urine samples were positive for crystals. Urine analysis revealed that the highest percent of urinary crystals were found among children from Abo redeis (47.1\%), then Abo Zeneima (34.9\%), then Saint Katrin (31.5\%), then Ras Sidr (25.9 $\%)$ followed by Nuweiba (25.7\%) and lastly El- Tur (25.3 $\%)$.

Concerning the marked increase in prevalence and incidence of urolithiasis during the past several decades, evaluation of the possible causative factors has indicated that inappropriate dietary habits, overweight status, and lifestyle might play an important role in urinary stone formation. Increasing incidence of urolithiasis in Western countries resulting from changes in lifestyle factors, particularly in adults, has raised the attention of the dietary habits and nutritional status of patients with stone formation $[5,6]$.

The most frequent crystals in the urine of the examined children was oxalate (15.6\%), then uric acid (12.6\%), and less than $1 \%$ of the samples was positive for triple phosphate crystals. About $2.8 \%$ of the children (53 children) had more than one type of crystals, and about $71.1 \%$ of the examined children had no crystals in their urine.

In children, urolithiasis remains a significant problem with serious consequences. The types of stone formed depend mainly on the urine composition, which in turn, reflects the type of diet consumed. In the pediatric population, nutritional and metabolic causes of tubular reabsorption can contribute to stone formation [4].

In developing countries, nutritional factors can be a major factor in the formation of stones in poor children. This is caused by a nutritionally poor acidogenic diet, high in cereal and low in animal protein, calcium and phosphate, which leads to the formation of urine with a relatively high content of ammonium and urate ions, and consequently to the formation of ammonium acid urate crystals and stones. In countries where there is also a high intake of oxalate from leaves and vegetables, urinary oxalate is increased and, as a result, the ammonium acid urate stones often contain calcium oxalate as well. The stone problem is compounded by low urine volumes resulting in some areas from poor drinking water, and chronic diarrhea, and in others from the hot climate and fluid losses through the skin [7].

City was the most frequent risk factor for the 3 crystals (oxalate, uric acid and triple phosphate) followed by origin (Bedouin or urban) and consanguinity. Oxalate was significantly higher in El- Tur, followed by Abo Zeneima then Nuweiba. Uric acid seemed to be significantly higher in Abo Redeis followed by Ras Sidre then Saint Katrin. Triple phosphate was significantly higher in Saint Katrin followed by Abo Zeneima, then Nuweiba.

The etiology of pediatric urolithiasis is influenced by geographic area, extent of metabolic work up, and the definition specified for the diagnosis of each metabolic abnormality [4]. There are frequently several causes of stone formation. Besides chronic infection, metabolic disorders and urinary stasis, other conditions can represent a risk factor for stone development [8]; for instance, dietary habits and drinking water intake, as well as water composition, may play a role in the induction or development of urinary calculi. Metabolic abnormalities and infectious stones prevail in most series [9].

South Sinai lies in the hyperarid zone in North African belt with high summer temperature, low humidity and long rainless periods. Water supply is deficient both in quantity and quality. These might play a role in high rate of childhood urinary crystals [10].

There were no significant differences between males and females according to the type of crystals in urine, except for oxalate in which males were significantly higher than females.

This coincide with Robertson et al., [11] and Aggour et al., [4], who reported that calcium oxalate and uric acid stones are more frequent in males than in females whereas calcium phosphate and struvite stones are more prevalent in females.

Sarica et al., [2], reported that, Girls were found to be more prone to an overweight problem with increased urinary stone-forming risk factors than boys. 
Uric acid crystals were significantly higher in children from bedouine area compared to urban area. On the other hand, there were no significant differences between the two areas in relation to other types of crystals. Uric acid crystals were significantly higher in children with positive consanguinity.

DeFoor et al., [12] and Spivacow et al., [13], reported that, positive family history has been suggested as increasing the risk of stone formation.

In conclusion, prevalence of crystal in urine which predispose to stone formation is high among children in South Sinai. City was the most frequent risk factor for the three crystals and oxalate crystals were the most common crystal followed by uric acid crystals. Uric acid crystals are more common in bedouine area and in children with positive consanguinity.

\section{Acknowledgements}

We would like to acknowledge all the children who participated in this study and their parents, without their help, this study couldn't be completed.

\section{Statement of authorship}

All authors participated in the conception and design of the study, drafting the article and final approval of the version to be submitted.

\section{References}

1. Powell CR, Stoller ML, Schwartz BF, Kane C, Gentle DL, Bruce JE, et al. Impact of body weight on urinary electrolytes in urinary stone formers. Urology. 2000;55:825-30.
2. Sarica K, Eryildmm B, Yencilek F, and Kuyumcuoglu U. Role of overweight status on stone-forming risk factors in children: A prospective study. Urology. 2009;73:1003-7.

3. Ramello A, Vitale C, Marangella M. Epidemiology of nephrolithiasis. J Nephrol. 2000;13:S45-50.

4. Aggour A, Ziada AM, Abdel Hamid A, Abdel Rahman S, Morsi A. Metabolic stone composition in Egyptian children. Journal of Pediatric Urology. 2009;5:132-35.

5. Rutkowski P, Klassen A, Sebekova K, Bahner U, Heidland A. Renal disease in obesity: the need for greater attention. Journal of Renal Nutrition. 2006;16:216-23.

6. Siener R. Impact of dietary habits on stone incidence. Urol Res. 2006;34:131-33.

7. Gault MH, Chafe L. Relationship of frequency, age and sex, stone weight and composition in 15,624 stones: comparison of results for 1980 to 1983 and 1995 to 1998. J Urol. 2000;164(2):302-7.

8. Stapleton FB. Clinical approach to children with urolithiasis. Semin Nephrol. 1996;16:389-97.

9. Basaklar AC, Kale N. Experience with childhood urolithiasis. Report of 19 cases. Br J Urol. 1991;67:203- 6.

10. South Sinai Environmental and Developmental Profile.SEAM programmed. INTEC Limited Co. and ERM co. U.K., 2005:69 - 77.

11. Robertson WG, Peacock M, Heyburn PJ. Clinical and metabolic aspects of urinary stone disease in leads. Scand J Urol. 1980;53(Suppl):199-205.

12. DeFoor WR, Jackson E, Minevich E, Caillat A, Reddy P, Sheldon $C$, et al. The risk of recurrent urolithiasis in children is dependent on urinary calcium and citrate. Pediatric Urology. 2010;76(1):242-45.

13. Spivacow FR, Negri AL, del Valle EE, Calviño I, Fradinger $\mathrm{E}$, Zanchetta JR. Metabolic risk factors in children with kidney stone disease. Pediatr Nephrol. 2008;23:1129-33. 